\title{
Intact and fragmented intracellular immunoglobulin in a case of non-secretory myeloma
}

\author{
J. T. WHICHER ${ }^{1}$, J. D. DAVIES, AND J. A. GRAYBURN
}

From the Department of Chemical Pathology, Bristol Royal Infirmary, the Department of Pathology, The University of Bristol Medical School, and the University Department of Medicine, Bristol Royal Infirmary

SYNOPSIS A patient is described with myeloma without paraproteinaemia or Be uria in whom the tumour cells have been of immunoelectrophoresis and polyacrylamide gel electrophoresis has established, apparently fo the first time, that the immunoglobulin components are present in the form of intact molecules and free light chains.

Myeloma without monoclonal immunoglobulin in the serum or urine has been reported to occur in about $1 \%$ of myeloma patients (Osserman and Takatsuki, 1963; Hobbs, 1969). Hobbs (1967) showed the presence of intracellular immunoglobulin in two such cases by immunoelectrophoresis of tumour cell homogenates. In recent years several such cases have been studied by electron microscopy and immunofluorescence of the tumour cells. In the majority of these, and also in non-secretory examples of other types of immunocytoma, the presence of monoclonal immunoglobulin within the tumour cells has been demonstrated (see table); negative

${ }^{1}$ Correspondence: Dr J. T. Whicher, Department of Chemical Pathology, Bristol Royal Infirmary, Bristol BS2 8HW.

Received for publication 25 September 1974. results were obtained by immunofluorescence $\overrightarrow{i 0}$ two other cases of non-secretory myeloma (Gasby Simar, and Salmon, 1971; River, Tewksbury, and Fudenberg, 1972).

Although some of these immunofluorescence studies suggest the presence of free immunoglobuli chains within the cell, they do not, as pointed out bo Arend and Adamson (1974), constitute unequivoca evidence for this.

We report a patient with non-secretory myeloma in whom, in addition to showing the presence of intact monoclonal immunoglobulin within the tumour cells, we have demonstrated the presence immunoglobulin fragments as free light chains is monomeric and dimeric forms. The significance of these findings in relation to the mechanism of secretory failure is discussed.

\begin{tabular}{|c|c|c|c|}
\hline \multirow[t]{2}{*}{ Author } & \multirow[t]{2}{*}{$\begin{array}{l}\text { Number of } \\
\text { Cases }\end{array}$} & \multicolumn{2}{|c|}{$\begin{array}{l}\text { Immunofluorescent Findings of Intracellular } \\
\text { Immunoglobulin }\end{array}$} \\
\hline & & Heavy Chain & Light Chain \\
\hline $\begin{array}{l}\text { Myeloma } \\
\text { Ryckewaert, Kuntz, Bonhomme, Preud'homme, Hurez, and } \\
\text { Seligmann (1969) } \\
\text { Hurez, Preud'homme, and Seligmann (1970) }\end{array}$ & $\begin{array}{l}1 \\
2\end{array}$ & $\begin{array}{l}x \\
x\end{array}$ & $\begin{array}{l}\lambda \\
\lambda \text { dubious stain }\end{array}$ \\
\hline $\begin{array}{l}\text { Delbarre, Siguier, Godeau, Saporta, Seligmann, and Hurez (1970) } \\
\text { Menkes, Hereman, Preud'homme, Godeau, and Delbarre (1972) } \\
\text { Arend and Adamson (1974) }\end{array}$ & $\begin{array}{l}2 \\
1 \\
1 \\
1 \\
1\end{array}$ & $\begin{array}{l}\gamma \text { dubious staining } \\
\text { Not detected } \\
\alpha \\
\gamma \text { dubious staining } \\
\gamma \text { weak staining }\end{array}$ & $\begin{array}{l}\kappa \\
\kappa \\
\lambda \\
\kappa \\
\kappa\end{array}$ \\
\hline $\begin{array}{l}\text { Chronic Lymphatic Leukaemia } \\
\text { Hurez, Flandrin, Preud'homme, and Seligmann (1972) } \\
\text { Cawley, Barker, Britchford, and Smith (1973) }\end{array}$ & $\begin{array}{l}1 \\
1\end{array}$ & 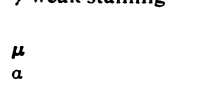 & $\begin{array}{l}\lambda \\
\lambda\end{array}$ \\
\hline $\begin{array}{l}\text { Malignant Lymphoma } \\
\text { Kaiserling, Stein, and Lennert (1973) }\end{array}$ & 2 & $\begin{array}{l}\mu \text { Determined by } \\
\text { immunodiffusion }\end{array}$ & Not specified \\
\hline
\end{tabular}

Table Previously reported observations on intracellular immunoglobulins in non-secretory myeloma 


\section{Case Report}

\section{CLINICAL FEATURES}

A 69-year-old woman presented with pain and difficulty in moving her left shoulder following a blow. Radiographs revealed a fracture of the clavicle with osteoporosis. Healing was unsatisfactory and further radiographs one month later demonstrated a large lytic lesion in the bone with similar lesions in the skull vault, mandible, both humeri and femora. The appearances were typical of myeloma. No clinical or radiological evidence of a primary carcinoma was found.

\section{LABORATORY INVESTIGATIONS}

The haemoglobin, white cell count, platelet count, blood film, and sedimentation rate were normal, as were the liver function tests, plasma electrolytes, and urea. The serum calcium was $2.6 \mathrm{mmol} / \mathrm{l}$; phosphate $1.42 \mathrm{mmol} / \mathrm{l}$; alkaline phosphatase 9 $\mathrm{KA} / 100 \mathrm{ml}$; serum albumin $48 \mathrm{~g} / 1$; total proteins $68 \mathrm{~g} / \mathrm{l}$; serum immunoglobulins estimated by radial immunodiffusion were $\operatorname{IgA} \mathbf{0} \cdot 62 \mathrm{~g} / \mathrm{l}$ (normal $1 \cdot 4-4 \cdot 2$ $\mathrm{g} / \mathrm{l}$ ); IgG 6.25 g/l (normal 8-12 g/l); IgM 0.34 g/l (normal 0.5-1.9 $\mathrm{g} / \mathrm{l}$ ).

Cellulose acetate electrophoresis of the serum showed no paraprotein, and immunoelectrophoresis was normal. There was no cryoglobulin present. The urine total protein was less than $0.05 \mathrm{~g} / \mathrm{l}$ and, after concentrating the urine 300 -fold, no light chains could be found by immunoelectrophoresis (Hobbs, 1966). After 3000-fold concentration of the urine both $\kappa$ and $\lambda$ light chains were detected which were heterogeneous on cellulose acetate electrophoresis: this is a normal finding (Lindström, Williams, Swaim, and Freier, 1968). A sternal marrow aspiration and clavicular biopsy were performed. Cytology and histology of the latter revealed plasmacytoid cells (detailed below).

Immunofluorescence studies of the tumour cells and immunoelectrophoresis of a tumour cell homogenate revealed that the tumour cells contained monoclonal immunoglobulin as described below.

The diagnosis of a malignant immunocytoma was thus established and treatment was commenced with Melphalan $15 \mathrm{mg}$ per day and prednisone 150 mg per day for four days. To date she has received multiple courses at six-weekly intervals and local irradiation to the left clavicle. A further bone marrow examination, performed just before the beginning of her second course of chemotherapy, revealed considerable numbers of plasmacytoid cells many of which contained multiple small, bluish, centrally situated intranuclear inclusions, such as have been described in secretory myeloma by Brittin, Tanaka, and Brecher (1963).

\section{Morphology of the Tumour}

Light microscopy was performed on formalin-fixed paraffin-embedded material stained with haematoxylin-eosin and methyl green-pyronin and on air-dried methanol-fixed smears stained with MayGrünwald-Giemsa. Electron microscopy was performed on the paraffin-embedded tissue which was reprocessed (Hübner, 1970) and embedded in Epon after glutaraldehyde and osmic acid fixation. Ultrathin sections were stained with uranyl acetate and lead citrate and examined in a Philips EM 300.

Light microscopy of the formalin-fixed paraffinembedded material from the clavicular lesion showed pleomorphic cells with prominent pyroninophilic cytoplasm which stained purple in the haematoxylineosin preparations. Their nuclei ranged from darkstaining, lymphocyte-like forms to multinucleate and vesicular nuclei with prominent nucleoli, but most were intermediate, plasmacytoid nuclei with peripherally situated condensed chromatin. Similar variations were seen in May-Grünwald-Giemsastained smears in which occasional round blue nuclear inclusions were also seen. Light microscopy of the tissue reprocessed for electron microscopy also showed that many of the nuclei were deeply notched (fig 1).

Electron microscopy of the reprocessed material showed many of the artefactual losses to be expected in such tissue (Ashworth and Stembridge, 1964; Hübner, 1970), namely, loss of Golgi apparatus,

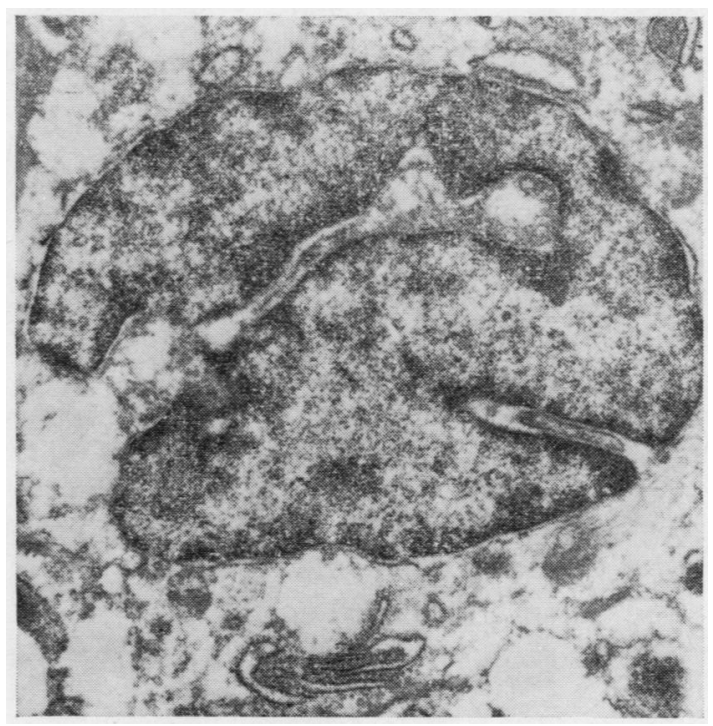

Fig 1 Nucleus of myeloma cell shows deep indentations, one of which contains (lower right) granular endoplasmic reticulum. $\times 20000$ 
peripheral cytoplasm, and mitochondrial structure. Nevertheless the nuclear structure was reasonably preserved and had the appearances described in earlier accounts of the ultrastructure of myeloma cells (Maldonado, Brown, Bayrd, and Pease, 1966a and b). Parts of the rough endoplasmic reticulum were preserved in the majority of the cells: in a few cells it assumed a bizarre whorled appearance. Dilatation of the endoplasmic reticulum was variable. In places the dilated sacs contained finely granular material, whereas elsewhere there were uniformly electron-dense globules, or, less frequently, reticular accumulations of moderately electron-dense material with a central cavity that was closely applied to a lining membrane. Indentations of the nuclear membrane contained further dense globules (fig 2), and nuclear inclusions appeared to be a mixture of cytoplasmic invaginations and intranuclear dense bodies similar to those found in the rough endoplasmic reticulum of the cytoplasm. Cytoplasmic fibrils, similar to those described in secretory myelomas (Smetana, Hermanský, Kobližková, and

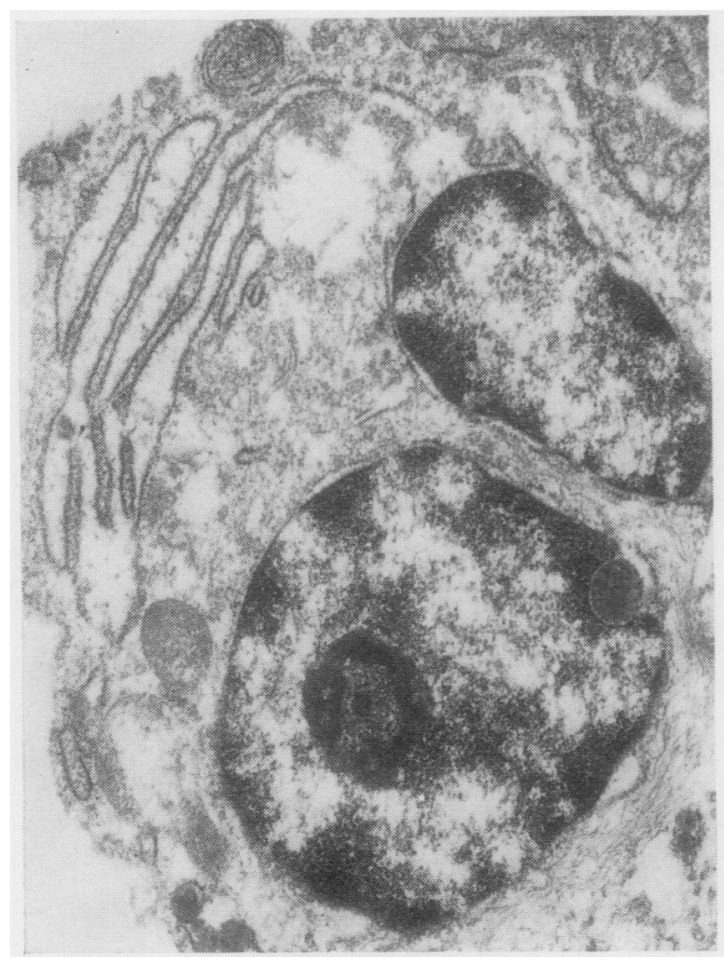

Fig 2 Dilated sacs of endoplasmic reticulum (left) contain granular material Dense body in upper pole of lower profile of nucleolated nucleus. Perinuclear cytoplasmic fibrils (lower right). $\times 27000$
Pospísil, 1971; Cawley and Hayhoe, 1973), werè present in the cytoplasm of scattered cells (fig 2). $\stackrel{\vec{\rho}}{\stackrel{(}{Q}}$

\section{Immunofluorescence}

Immunofluorescence was performed both on froze sections of unfixed tumour and on a washed cedf homogenate using the technique described by Solomon, Fahey, and Malmgren (1963). Fluorescent staining was achieved by a double antibody method employing monospecific rabbit antisera to humapp immunoglobulins and fluorescein-conjugated swing antirabbit IgG (supplied by Dakopatts A/S, Copeno hagen). Preparations were examined with a Zeiș Standard Universal fluorescence microscope fitted with a HBO $200 \mathrm{~W} / 4$ mercury vapour lamp and vertical illumination.

Frozen sections of the tumour showed strong cytoplasmic fluorescence with antisera to $\gamma$ and chains in the majority of the tumour cells. Occasiona small lymphocytes and the walls of blood vessets showed fluorescence with anti $\mu$. There was ver $\overrightarrow{B b}$ faint fluorescence between the cells with anti $\alpha$ and anti $\lambda$.

Immunofluorescence carried out on a washed ce suspension revealed fluorescence of intact cells and cell debris with anti $\gamma$ and anti $\kappa$, despite the fat that the cells were somewhat damaged by th process. There were no fluorescent intranucleaf inclusions although there was fluorescence of some of the clefts within the nuclei (fig 3).

\section{Immunoelectrophoresis}

Tumour tissue from the clavicle was immediately prepared for immunoelectrophoresis and the remain. der snap frozen and stored at $-20^{\circ}$.

Tumour tissue, $0.5 \mathrm{~g}$, was lightly homogenize in a Griffiths tube to produce a finely particulate suspension which was washed in three changes of $15 \mathrm{ml}$ of $0 \cdot 15 \mathrm{M}$ sodium chloride solution. This w then re-homogenized by a similar method for longer period, to break up the cells. Samples (3 $\mu$ l) of the whole homogenate were electros phoresed in agar and diffused against antisera human $\gamma, \alpha, \mu, \kappa$, and $\lambda$ chains (supplied by Dakepatts A/S, Copenhagen).

The tumour extract developed precipitin lines against IgG heavy chain and $\kappa$ light chain antiserẹ When antiwhole human serum or a mixture of anti $\gamma$ and anti $\kappa$ was used there was marked spurring of the $\kappa$ line from the $\gamma$ line suggesting the presen of free chain of one type. This was supported to Ouchterlony immunodiffusion of the tumour extragf against $\kappa$ and $\gamma$ antisera when marked spurring of the $\kappa$ line over the $\gamma$ line was seen (fig 4). 


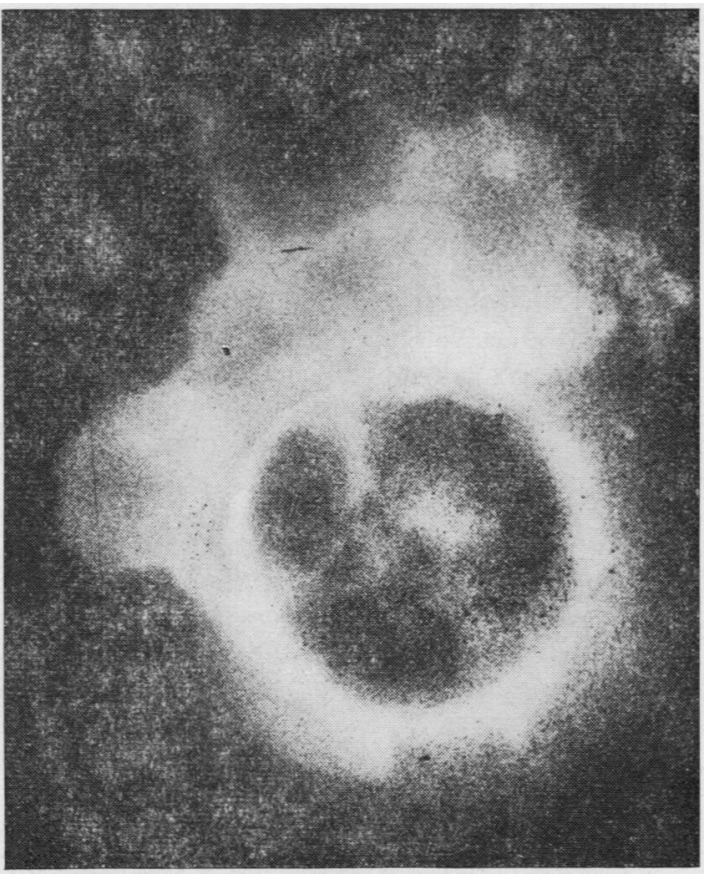

Fig 3 Plasma cell fluorescing with $\kappa$ antiserum. Invaginations of fluorescence into the nucleus can be seen. $\times 4000$

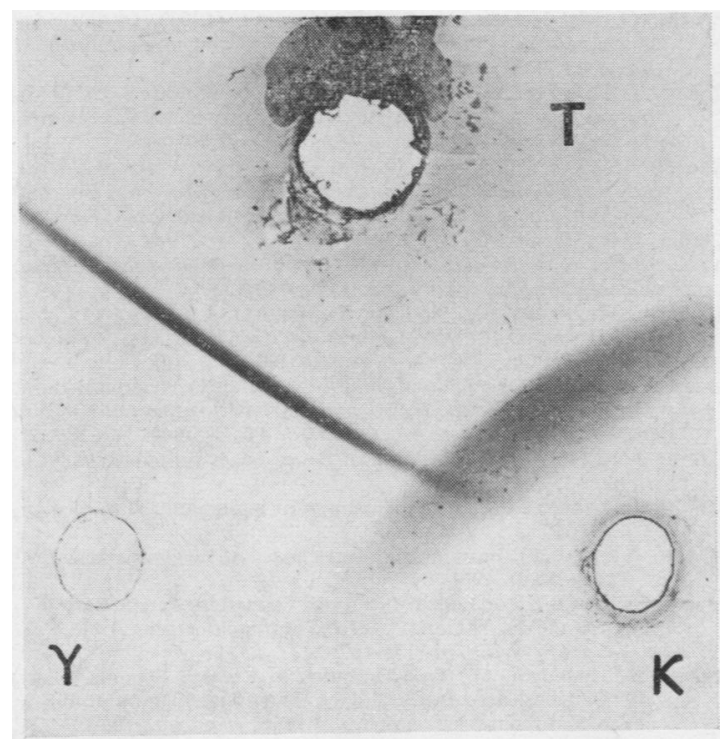

Fig 4 Ouchterlony diffusion of tumour extract against IgG heavy chain and $\kappa$ light chain antisera demonstrating spurring of the $\kappa$ line over the $\gamma$.

\section{Sodium Dodecyl Sulphate (SDS) Polyacrylamide} Gel Electrophoresis

The tumour homogenate was extracted with a minimum volume of sodium dodecyl sulphate in phosphate buffer, $0.6 \mathrm{M}, \mathrm{pH} 7 \cdot 2$, and the extract separated in polyacrylamide gel according to the technique described by Summers, Maizel, and Darnell (1965). Identification of the protein bands was achieved by immunodiffusion against specific antisera in agar (Virella and Parkhouse, 1971). These methods revealed the presence of three immunoglobulin bands. The highest molecular weight band reacted with both $\gamma$ and $\kappa$ antisera. The second band, in a position corresponding to a $\kappa$-dimer Bence Jones protein marker, reacted only with $\kappa$ antiserum, as did the third band which corresponded with a $\kappa$-monomer Bence Jones protein marker. These three bands thus represent intact IgG molecules, type $\kappa$, and $\kappa$ light chains probably as dimer and monomer respectively.

\section{Discussion}

Thestudies summarized in the table show that in some cases of non-secretory myeloma synthesis of monoclonal immunoglobulin occurs and that there may be an imbalance in the intracellular concentration of heavy and light chains in some of the cases. However the relative potency of antisera may vary and therefore the immunofluorescent observations are not indisputable evidence of the existence of free chains, nor does the presence of both heavy and light chains necessarily mean that they are present as intact immunoglobulin molecules.

Our case is of interest because the use of immunoelectrophoresis and SDS polyacrylamide gel electrophoresis does enable the molecular nature of the heavy and light chains to be established, and show, for the first time so far as we are aware, that the cells contain intact immunoglobulin molecules (IgG, $\kappa$ ) together with free light chains $(\kappa)$, the latter in monomeric and dimeric forms.

The reason for the failure of immunoglobulin release from the cell in non-secretory myelomas is obscure. Current concepts concerning the pathway for immunoglobulin synthesis and secretion have been reviewed by Schubert and Cohn (1968). It is thought to proceed as follows: light chains and heavy chains are produced on different polyribosomes, the rate of light chain release being twice that of heavy chain. The combination of light chains with nascent heavy chains is followed by the union of two H-L molecules to form the intact immunoglobulin molecule. The excess free light chain is largely destroyed within the cell, only a very small 
amount normally escaping, in contrast to many myelomas where there is probably a failure of intracellular degradation of free light chains which escape from the cell to be excreted as Bence Jones protein (McLaughlin and Hobbs, 1973).

Secretion of immunoglobulin is probably dependent on transport through the endoplasmic reticulum, and a specific transport protein has been postulated which recognizes light chains. The part of the light chain which is recognized is uncertain but it is probably not the carbohydrate moiety as this is added to the molecule after transport through the endoplasmic reticulum, and myelomas secreting light chains without carbohydrate are well documented (Abel, Spiegelberg, and Grey, 1968; Clamp, Bernier, and Putnam, 1964). It is possible that the factors governing recognition of light chains lie in that part of the molecule which is common to both $\kappa$ and $\lambda$ light chains, eg, Ala-Ala-Pro-Ser-Val at the beginning of the constant region of human $\kappa$ and $\lambda$ chains (Lennox and Cohn, 1967).

Failure to secrete immunoglobulin might thus be due to some defect in the light chain constant region, in the transport protein, or in the structural integrity of the endoplasmic reticulum or Golgi apparatus.

The suggestion that secretion depends on recognition of the light chain is in accordance with our findings that failure to excrete the whole immunoglobulin molecule is accompanied by failure to excrete the free light chains shown to be present.

Intranuclear inclusions, such as were seen in this case, have been well described in myeloma (Bessis, 1973) and have been shown to contain immunoglobulin in several cases (Brittin et al, 1963), including two of non-secretory myeloma (Hurez, Preud'homme, and Seligmann, 1970). Their nature has been discussed at length by Brittin et al (1963) who, while considering the possibility that some of them may be sections of cytoplasmic invaginations into the nucleus, ultimately conclude that most of them represent the production of immunoglobulin within the nucleus. In our case the intranuclear inclusions did not fluoresce, so presumably contained neither intact immunoglobulin nor free light chains. However the presence of protein within the nucleus does not necessarily imply a nuclear origin. The nuclear clefts visible by light microscopy in our case were shown by electron microscopy to consist of cytoplasmic invaginations some of which, but not all, contained endoplasmic reticulum filled with electrondense material presumed to be immunoglobulin. Some of these clefts fluoresced, as is shown by the enlarged photomicrograph (fig 3). Clearly, if seen in cross section, such invaginations would have the appearance of discrete intranuclear bodies containing immunoglobulin components, while non-fluorescent bodies might represent similar invaginations which do not contain immunoglobulin.

This case thus represents a B-cell tumour with the clinical and morphological features of multip myeloma in which intracellular immunoglobuli was present and demonstrable by immunoelectr $\vec{\sigma}$ phoresis of the tumour cell homogenate. In view at the ease of this procedure we concur with Hobbs (1967) view that this is a valuable aid to the diagnosis of the $1 \%$ of myeloma patients who secrete na paraprotein. Its advantage over cellular immun fluorescent studies is that it is possible to investigato the molecular characteristics of the immunoglobulion in the tumour.

We are grateful to Dr M. Hartog and Dr J. Verriễ Jones for permission to publish the clinical detaifs of this case, to Messrs ( $\mathrm{j}$. Roberts and G. Ball for the microscopic preparations, and to Dr G. Walte for helpful criticism.

\section{References}

Abel, C. A., Spiegelberg, H. L., and Grey, H. M. (1968). The carbbhydrate content of fragments and polypeptide chains of human $\gamma$ G-myeloma proteins of different heavy chain subclasse? Biochemistry, 7, 1271-1278.

Arend, W. P., and Adamson, J. W. (1974). Non secretory myelom immunofluorescent demonstration of paraprotein within bo marrow plasma cells. Cancer (Philad.), 33, 721-728.

Ashworth, C. T., and Stembridge, V. A. (1964). Utility of formali® fixed surgical and autopsy specimens for electron microscop Amer. J. clin. Path., 42, 466-480.

Bessis, M. (1973). Living Blood Cells and Their Ultrastructure, p. 63 Springer, Berlin.

Brittin, G. M., Tanaka, Y., and Brecher, G. (1963). Intranucleă inclusions in multiple myeloma and macroglobulinemia: Blood, 21, 335-351.

Cawley, J. C., Barker, C. R., Britchford. R. D., and Smith, J. L. (197年 Intracellular IgA immunoglobulin crystals in chronic lympbr ocytic leukaemia. Clin. exp. Immunol., 13, 407-416.

Cawley, J. C., and Hayhoe, F. G. J. (1973). Ultrastructure of Haen cells. A Cytological Atlas of Normal and Leukaemic Blood arf

Bone Marrow, p. 245. Saunders, London, Philadelphia, Toront?
Clamp, J. R., Bernier, G. M., and Putnam, F. W. (1964. The source of the apparent carbohydrate content of Bence-Jones proteiQ Biochim. biophys. Acta (Amst.), 86, 149-155.

Delbarre, F., Siguier, F., Godeau, P., Saporta, L., Seligmann, MD and Hurez, D. (1970). La maladie de Kahler à plasmocyte 'non excrétants'. Ann. Méd. intern., 121, 537-544.

Gach, J., Simar, L., and Salmon, J. (1971). Multiple myeloma withof M-type proteinemia: report of a case with immunologic and ultrastructure studies. Amer. J. Med., 50, 835-844. Hobbs, J. R. (1966). The detection of Bence-Jones proteins. Biocherev
J., 99, 15p.

Hobbs, J. R. (1967). Paraproteins, benign or malignant? Brit. med. 3, 699-704.

Hobbs, J. R. (1969). Immunochemical classes of myelomatosis. Br J. Haemat., 16, 599-606.

Hübner, G. (1970). Zur Feinstruktur von formalinfixiertem Biopsie und Autopsie Material nach Paraffineinbettung. Virchowis Arch. path. Anat., 351, 155-167.

Hurez, D., Flandrin, G., Preud'homme, J. L., and Seligmann, (1972). Unreleased intracellular monoclonal macroglobulin $\frac{\mathbb{D}}{4}$ chronic lymphatic leukaemia. Clin. exp. Immunol., 10, 223-239

Hurez, D., Preud'homme, J. L., and Seligmann, M. (1970). Intr震 cellular 'Monoclonal' immunoglobulin in non-secretory human myeloma. J. Immunol., 104, 263-264.

Kaiserling, E., Stein, H., and Lennert, K. (1973). IgM-producing malignant lymphomas without macroglobulinemia. Morphळ 
logical and immunochemical findings. Virchows Arch. Abt. B. Zellpath., 14, 1-18.

Lennox, E. S., and Cohn, M. (1967). Immunoglobulins. Ann. Rev. Biochem., 36, 365-406.

Lindström, F. D., Williams, R. C., Jr., Swaim, W. R., and Freier, E. F. (1968). Urinary light-chain excretion in myeloma and other disorders - an evaluation of the Bence Jones test. J. Lab. clin. Med., 71, 812-825.

McLaughlin, H., and Hobbs, J. R. (1973). Clinical significance of Bence-Jones proteinuria. Protides biol. Fluids, 20, 251-254.

Maldonado, J. E., Brown, A. L. Jr.,, Bayrd, E. D., and Pease, G. L. (1966a). Ultrastructure of the myeloma cell. Cancer (Philad.), 19, 1613-1627.

Maldonado, J. E., Brown, A. L., Jr., Bayrd, E. D., and Pease, G. L. (1966b). Cytoplasmic and intranuclear electron-dense bodies in the myeloma cell. Arch. Path., 81, 484-500.

Menkes, C. J., Herreman, G., Preud'homme, J. L., Godeau, P., and Delbarre, F. (1972). Myélome à plasmocytes non excrétants. Nouv. Presse méd., 1, 309-312.

Osserman, E. F., and Takatsuki, K. (1963). Plasma cell myeloma: gamma globulin synthesis and structure. Medicine (Baltimore) 42, 357-384.
River, G. L., Tewksbury, D. A., and Fudenberg, H. H. (1972). 'Nonsecretory' multiple myeloma. Blood, 40, 204-206.

Ryckewaert,'A., Kuntz, D., Bonhomme, J., Preud'homme, J. L., Hurez D., and Seligmann, M. (1969). Un cas de myélome non sécrétant avec déminéralisation vertébrale diffuse et rétention intracellulaire de la globuline myélomateuse. Rev. Rheum., 36, 621-624.

Schubert, D., and Cohn, M. (1968). Immunoglobulin biosynthesis. III. Blocks in defective synthesis. J. molec. Biol., 38, 273-288.

Smetana, K., Hermanský, F., Kobližkková, H., and Pospisil, V. (1971) A further note on the ultrastructure of myeloma plasmacytes. Neoplasma, 18, 3-13.

Solomon, A., Fahey, J. L., and Malmgren, R. A. (1963). Immunohistological localization of gamma-1-macroglobulins, beta-2A myeloma proteins, 6.6S Gamma-myeloma proteins and Bence Jones proteins. Blood, 21, 403-423.

Summers, D. F., Maizel, J. V., Jr., and Darnell, J. E. Jr., (1965). Evidence for virus-specific noncapsid proteins in poliovirusinfected Hela cells. Proc. nat. Acad. Sci. (Wash.), 54, 505-513.

Virella, G., and Parkhouse, R. M. E. (1971). Detection of monomeric IgM by acrylamide disc gel electrophoresis followed by agar gel immunodiffusion. Clin. chim. Acta, 32, 427-431. 